\title{
Lif Kabağı Takviye Edilmiş Kitosan-İpek Hidrojel Kompozit Doku İskelelerinin Kıkırdak Doku Hasarı Tedavisinde Kullanımının Araştırılması
}

\author{
Investigation of the Loofah Reinforced Chitosan-Silk \\ Hydrogel Composite Scaffolds for Cartilage Tissue \\ Regeneration
}

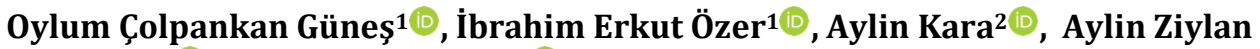 \\ Albayrak $^{1^{*}}{ }^{\oplus}$, Hasan Havitçıoğlu ${ }^{3}$ (1) \\ ${ }^{1}$ Dokuz Eylül Üniversitesi, Mühendislik Fakültesi, Metalurji ve Malzeme Mühendisliği Bölümü, İzmir, TÜRKIYE \\ 2 İzmir Yüksek Teknoloji Enstitüsü, Biyoteknoloji ve Biyomühendislik Programı, Urla, İzmir, TÜRKIYE \\ ${ }^{3}$ Dokuz Eylül Üniversitesi, Tıp Fakültesi, Ortopedi ve Travmatoloji Anabilim Dalı, İzmir, TÜRKIYE \\ Sorumlu Yazar / Corresponding Author*: avlin.albayrak@deu.edu.tr \\ Geliş Tarihi / Received: 12.11.2020 \\ Araştırma Makalesi/Research Article \\ Kabul Tarihi / Accepted: 22.04.2021 \\ DOI:10.21205/deufmd.2021236921 \\ Atıf sekli/How to cite: GÜNES O.C..,ÖZER İ.E., KARA A., ZIYLAN ALBAYRAK A., HAVITÇIOĞLU H.(2021). Lif Kabağı Takviye Edilmiș Kitosan-İpek \\ Hidrojel Kompozit Doku İskelelerinin Kıkırdak Doku Hasarı Tedavisinde Kullanımının Araştırılması. DEÜFMD 23(69), 937-950.
}

\section{$\ddot{0} \mathbf{z}$}

Kıkırdak doku hasarlarının onarılmasındaki mevcut tedaviler, kıkırdağın kendi kendini iyileştirme kapasitesinin düşük olması nedeni ile sınırlıdır. Son yıllarda doku mühendisliği, kıkırdak rejenerasyonu için umut verici bir yaklaşım olarak önerilmektedir. Bu çalışmada, kıkırdak doku hasarları için lif kabağı ile güçlendirilmiş ipek fibroin/kitosan hidrojeller hazırlanmıştır. Biyouyumlu, biyolojik olarak parçalanabilir ipek fibroin ve kitosan polimerleri, doğal ve toksik olmayan bir çapraz bağlama maddesi olan genipin ile çapraz bağlanmıștır. Taramalı elektron mikroskobu (SEM) ve Fourier Dönüşümü Kızılötesi Spektroskopisi (FTIR) sırasıyla morfoloji ve kimyasal yapı karakterizasyonu için kullanılmıștır. Viskoelastik özelliklerin belirlenmesi için dinamik mekanik analiz cihazı (DMA) kullanılırken, iskelelerin mekanik özelliklerini incelemek için basma testi kullanılmıștır. Doku iskelelerinin sitotoksisitesi, hücre canlılığı ve çoğalması tavşan mezenkimal kök hücreleri kullanılarak LDH, WST ve kollajen testi ile araştırılmıștır. Üretilen hidrojel kompozit doku iskelelerinin tamamının birbirine bağlı mikro gözenekli bir yapıya sahip olduğu ve lif kabaklarının yapıya iyi entegre olduğu görülmektedir. Ağırlıkça \%0,3 genipin ile çapraz bağlanan hidrojel kompozit doku iskelesi (L-CSG3), eklem kıkırdağıyla karşılaștırılabilir su içeriği $(94,4 \pm \% 0,2)$, $\tan \delta$ $(1 \mathrm{~Hz}$ 'de 0,18$)$ ve basma modülü $(5,5 \mathrm{MPa})$ değerleri göstermiștir. Ayrıca, in-vitro test sonuçlarına göre, bu hidrojel kompozit doku iskelesi, tavşan mezenkimal kök hücrelerinde gelişmiş canlılık göstermiştir. Sonuç olarak, bu hidrojel kompozit doku iskelesi, kıkırdak dokusu rejenerasyonu için umut vaat ettiği söylenebilir.

Anahtar Kelimeler: Lif kabağı, kitosan, ipek, hidrojel doku iskelesi, kıkırdak rejenerasyonu

\section{Abstract}

Current therapies for the treatment of cartilage defects are limited due to the low self-healing capacity of cartilage. In recent years, tissue engineering has been proposed as a promising approach for cartilage regeneration. In this study, silk fibroin/chitosan hydrogels reinforced with luffa cylindrica 
were prepared for cartilage tissue defects. Biocompatible, biodegradable silk fibroin and chitosan polymers were cross-linked with genipin which is a natural and nontoxic cross-linking agent. Scanning electron microscopy (SEM) and Fourier Transform Infrared Spectroscopy (FTIR) were used for the characterization of the morphology and chemical structures, respectively. Dynamic mechanical analysis was used to determine the viscoelastic properties, while compression test was applied to examine the mechanical properties of the scaffolds. The cytotoxicity, viability and proliferation of rabbit mesenchymal stem cells on the scaffolds were investigated by LDH, WST, and collagen assay. All of the produced hydrogel composite scaffolds had an interconnected microporous structure and loofah nanofibers were well-integrated within the structure. The hydrogel composite scaffold cross-linked with $0.3 \%$ wt. genipin (L-CSG3) demonstrated comparable water content $(94.4 \pm 0.2 \%), \tan \delta(0,18$ at $1 \mathrm{~Hz})$ and compressive modulus $(5,5 \mathrm{MPa})$ values to that of articular cartilage. Besides, based on the in-vitro test results, this hydrogel composite scaffold showed enhanced viability on rabbit mesenchymal stem cells. Consequently, this hydrogel composite scaffold presented a great promise for cartilage tissue regeneration.

Keywords: Loofah, chitosan, silk, hydrogel scaffold, cartilage regeneration

\section{Giriş}

Kollajen lifleri, proteoglikanlar ve sudan oluşan kıkırdaklı bir matristen (ECM) ve matris içinde dağılmış kondrositlerden oluşan eklem kıkırdağı; kemikleri bir arada tutma, tekrarlayan yüklemelere dayanma ve eklem kısmını darbeye dayanıklı hale getirme gibi işlevlere sahiptir. Ancak, doğrudan kan veya sinir kaynağının olmaması nedeniyle kendi kendini onarma yeteneği sınırlıdır [1,2]. Kıkırdak hasarında kullanılan geleneksel teknikler, uzun ömürlü kıkırdak dokusu olușturmak için çok başarılı olmamakta ve ayrıca ağrı, donör bölge morbiditesi ve enfeksiyon riski gibi yan etkiler de göstermektedirler [3]. Son yıllarda doku mühendisliği, kıkırdak rejenerasyonu için umut verici bir yaklaşım olarak önerilmektedir [4]. Hücre tutunması, çoğalması, farklılașması ve yeni doku oluşumu için üç boyutlu bir mikro ortam sağlamayan doku iskelesi, biyouyumlu, biyolojik olarak parçalanabilir ve besinlerin ve oksijenin verimli bir şekilde taşınmasına izin vermek için gözenekli yapıda olmalıdır [5]. Doku iskelesi ayrıca kondrosit hücre davranıșını modüle etmek için kıkırdak hücre dıșı matriksin bileşimini, yapısını, morfolojisini ve biyoaktivitesini taklit etmelidir [6]. Doğal bir polisakkarit olan kitosan, kıkırdak ECM'indeki glikozaminoglikanlara yapısal benzerliği, biyobozunur ve biyouyumlu özellikleri nedeni ile büyük ilgi görmektedir [7]. Lifsi bir protein olarak tanımlanan ipek biyopolimeri, biyouyumluluğu, biyobozunurluğu ve fonksiyonel modifikasyonlar için kolayca erișilebilir kimyasal gruplarının varlığı nedeniyle biyomedikal uygulamalarda yaygın olarak kullanılmaktadır [8]. Doğal biyopolimerler, her ne kadar yüksek biyouyumlulukları nedeni ile tercih edilseler de mekanik özellikleri yeterli değildir. Bu nedenle, kompozit doku iskeleleri, yüksek biyouyumluluğu korurken, istenen mekanik özellikleri sağlamak için önemli hale gelmiştir [9]. Kıkırdaklı ECM'nin kompozit yapısı, özellikle dinamik yükleme sırasında, yük taşıyan eklemlerde kritik bir rol oynamakta ve ayrıca, viskoelastisite ve gerilim gevșemesi gibi karmaşık mekanik özellikler sağlamaktadır. Bu nedenle, kıkırdak doku mühendisliği için biyomimetik fiber takviyeli hidrojel doku iskelelerin geliştirilmesi büyük önem taşımaktadır [10,11]. Lif kabağı, Cucurbitaceae bitki ailesine ait olan ve ağırlıklı olarak selüloz/hemiselüloz ve ligninden oluşan bir bitkidir. Liflerin çok yönlü bir dizide yerleștirilerek doğal bir mat oluşturduğu odunsu bir ağ sistemine sahiptir [12]. Hidrojeller, hidratlı yapıları ile kıkırdak ECM'nin hidrofilik ortamı arasındaki benzerlik nedeniyle kıkırdak doku iskelesi olarak büyük ilgi görmektedir. Hidrojeller, șişmiş hallerinde büyük miktarda su ve biyolojik sıvıyı tutabilen hafif çapraz bağlı, üç boyutlu ve çözünmez polimer ağlarıdır [13]. Doğal organik bir bileșik olan genipin, düşük sitotoksisitesinden dolayı yaygın bir çapraz bağlayıcı olarak kullanılmaktadır [14]. Bu çalıșmada, lif kabağı takviye edilmiș genipin ile çapraz bağlanmış üç boyutlu ve gözenekli ipek fibroin/kitosan hidrojel kompozit doku iskeleleri üretilmiş ve yapılan morfoloji, viskoelastik özellik ve basma dayanımı, biyouyumluluk çalıșmaları ile kıkırdak doku hasarlarında kullanılabilirliği araştırılmıştır. 


\section{Materyal ve Metot}

\subsection{Materyaller}

Çalışmada kullanılan kitosan (yüksek moleküler ağırlıklı, deasetilasyon derecesi $\geq 75$ ), asetik asit ve ipek çözeltisinin elde edilmesi sırasında kullanılan selüloz membran Sigma-Aldrich şirketinden satın alınmıştır. Bombyx mori ipek kozaları ve lif kabağı Kuzey Kıbrıs Türk Cumhuriyetinden tedarik edilmiştir. İpek çözeltisini hazırlamak için kullanılan, sodyum karbonat $\left(\mathrm{Na}_{2} \mathrm{CO}_{3}\right)$, kalsiyum klorür $\left(\mathrm{CaCl}_{2}\right)$ ve lif kabaklarının hazırlanmasında kullanılan sodyum hidroksit $(\mathrm{NaOH})$ Merck şirketinden satın alınmıştır. Doku iskelelerinin çapraz bağlanması ișleminde kullanılan genipin ise Wako Chemicals şirketinden tedarik edilmiştir.

Hücre kültürü çalışmalarında, DMEM-HG ve MEM besi ortamları ve tamamlayıcı kimyasallar Biochrome şirketinden satın alınmıştır. Farklılaștırma ajanı olarak kullanılan transforme edici büyüme faktörü- $\beta$ (TGF $\beta$ ), insülin büyüme faktörü (IGF), ITS+Premiks, isobütilmetilksantin ve indometasin Cell Signaling firmasından; hücre farklılaşmasının tayini için kullanılan alizarin kırmızısı, alcian mavisi, Oil red 0 boyaları Sciencell firmasindan temin edilmiştir. Akım sitometrik analizlerde kullanılan yüzey işaretleyiciler; CD 73 (APC antirabbit IgG1), CD 90 (FITC anti-rabbit IgG1), CD 34 (PE anti-rabbit IgG1), CD 45 (PerCP/Cy5.5 anti-rabbit IgG1) Abcam şirketinden satın alınmıștır. In-vitro analizlerde Laktat dehidrogenaz (LDH) Sitotoksisite Kit (Pierce LDH Cytotoxicity Assay Kit, Thermo Scientific), WST-1 Colorimetric Assay Kit (Biovision Inc.), Hidroksiprolin Colorimetrik Assay Kit (Elabscience Biotechnology Inc.) kullanılmıştır. Mezenkimal kök hücrelerin elde edilmesi için Yeni Zellanda Beyaz tavşanlar (diși, $3.5-4 \mathrm{~kg}$, $\mathrm{n}=3$ ) Dokuz Eylül Üniversitesi Laboratuvar Hayvanları Bilimi Anabilim Dalı'ndan temin edilmiştir. Dokuz Eylül Üniversitesi Tıp Fakültesi Hayvan Deneyleri Yerel Etik Kurulu'nun 49/2014 protokol numaralı izni ile uygun cerrahi ve post cerrahi işlemler kapsamında çalışmalar yürütülmüştür.

\subsection{Hidrojel kompozit doku iskelesi üretimi}

\subsubsection{Lif kabağının hazırlanması}

Çekirdekleri temizlenip, kesilen lif kabakları, üzerindeki yapışkan kısmın giderilmesi için ağırlıkça \%2'lik sodyum hidroksit $(\mathrm{NaOH})$ çözeltisi içerisinde 2 saat bekletilmiştir. Ardından, lif kabakları, nötral $\mathrm{pH}$ değeri elde edilene kadar saf su ile yıkanmış ve $60^{\circ} \mathrm{C}$ sıcaklıkta vakum etüvünde 24 saat boyunca kurutulmuştur. $3 \mathrm{~cm}$ çapında kesilerek hazırlanan lif kabakları, doku iskelesinde takviye malzemesi olarak kullanılmıştır.

\subsection{2. Çözeltilerin hazırlanması}

Hacimde ağırlıkça \%1'lik ipek çözeltisi elde etmek için ilk olarak, $1 \times 1 \mathrm{~cm}$ boyutunda kesilen ham ipek kozaları, üzerindeki serisin adı verilen yapışkan maddenin giderilmesi için 0,01 M sodyum karbonat $\left(\mathrm{Na}_{2} \mathrm{CO}_{3}\right)$ çözeltisi içerisinde $70^{\circ} \mathrm{C}^{\prime}$ de 3 saat karıştırılarak "degumming" adı verilen bir işleme tabi tutulmuştur. Bu işlem, üç kez tekrarlanmış ve ardından saf su ile yıkama gerçekleștirilmiştir. Daha sonra, serisinden arındırılmış ipek lifleri $\mathrm{CaCl}_{2} / \mathrm{CH}_{3} \mathrm{CH}_{2} \mathrm{OH} / \mathrm{H}_{2} \mathrm{O}$ üçlü çözeltisi içerisinde (1/2/8 molar oranı) $70^{\circ} \mathrm{C}$ 'de 6 saat boyunca çözündürülmüştür. Elde edilen ipek çözeltisi, filtreleme işlemi ardından saf su içerisinde selüloz membran yardımı ile 3 gün boyunca diyalize tabi tutulmuştur. Kitosan çözeltisi ise, \%2'lik asetik asit çözeltisi içerisinde ağırlıkça \%1 kitosan olacak şekilde $50^{\circ} \mathrm{C}$ sıcaklıkta 3 saat karıștırılarak hazırlanmıştır. Homojen bir çözelti elde etmek için karıştırma işlemi oda sıcaklığında gece boyunca devam ettirilmiştir.

\subsubsection{Hidrojel doku iskelesinin üretilmesi}

Hidrojel doku iskeleleri elde etmek için ilk olarak gözenekli kitosan-ipek ve lif kabağı takviyeli kitosan-ipek süngerler üretilmiş ve daha sonra süngerler genipin ile kovalent olarak çapraz bağlanmıştır.

İlk olarak, hazırlanan kitosan ve ipek çözeltileri hacimce 1:1 oranında karıștırılmıștır. Ardından hazırlanan homojen karışımın 4 ml'si cam şişe içerisindeki lif kabaklarına ilave edilmiş ve gece boyunca bekletilmiştir. Süngerler, $-60^{\circ} \mathrm{C}$ sicaklık ve 0,1 mbar basınç altında 2 gün boyunca dondurarak kurutma işlemi sonucunda elde edilmiștir. Süngerlere ipeğin suda çözünebilen $\alpha$-düzensiz sarmal yapısından suda çözünmeyen $\beta$-tabakalı yapısına dönüşmesinin sağlanması için 1 saatlik metanol işlemi uygulanmıştır. Daha sonra süngerler, asetik asidin ve metanolün giderilmesi amacı ile, giderek azalan etanol oranlı ( $\% 80, \% 60, \% 40, \% 20$ ve $\% 0$ etanol) etanol-su karışımlarıyla yıkanmıştır. Kontrol grubu olarak lif kabağı takviye edilmemiş kitosan-ipek süngerler üretilmiştir. 
Hidrojel yapıda doku iskelelerinin elde edilmesi için çapraz bağlayıcı olarak genipin kullanılmıştır. Farklı konsantrasyonlardaki genipin çözeltileri $(\% 0,1,0,3$ ve 0,5 ağırlık/hacim oranlarında), genipinin fosfat tamponlu salin (PBS) çözeltisi içerisinde oda sıcaklığında çözünmesi ile elde edilmiștir. Kontrol grubuna ve hazırlanan lif kabağ takviyeli kompozit süngerlere $4 \mathrm{ml}$ genipin çözeltisi ilave edilip, 48 saat gözlem sonucunda çapraz bağlanma süresi optimize edilmiştir.

\subsection{Hidrojel doku iskelelerinin} karakterizasyonu

Doku iskelelerinin morfoloji karakterizasyonları taramalı elektron mikroskobu (SEM, JEOL JSM6060) kullanılmıștır. Görüntüleme öncesinde doku iskeleleri püskürtümlü kaplama cihazı (Quorum Technologies, SC7620) kullanılarak altın/paladyum ince film tabakasıyla kaplanmıștır.

Üretilen doku iskelelerinin kimyasal yapı analizleri ATR ünitesi eklentili Fourier Dönüşümlü Kızılötesi Spektroskopisi (ATRFTIR) (Perkin Elmer Spectrum BX) cihazı ile gerçekleștirilmiştir. FTIR analizleri her örnek için 4000-650 $\mathrm{cm}^{-1}$ dalga boyu aralığında, $4 \mathrm{~cm}^{-1}$ çözünürlükte ve 25 tarama ile yapılmıștır.

Şişme testleri PBS çözeltisi içerisinde gerçekleştirilmiştir. Hazırlanmış olan doku iskelelerinin kuru ağırlıkları (wo) ölçüldükten sonra örnekler, $37^{\circ} \mathrm{C}$ 'de 24 saat boyunca PBS çözeltisi içerisinde bekletilmiştir. Örnekler üzerindeki fazla sıvının filtre kağıdı yardımıyla alınmasının ardından örneklerin yaş ağırlıkları $\left(w_{s}\right)$ ölçülmüștür. Doku iskelelerinin șișme oranı ve su içerikleri sırası ile denklem 1 ve denklem 2 kullanılarak elde edilmiştir.

$$
\begin{aligned}
& \text { Şişme oranı }(\%)=\frac{\left(w_{s}-w_{0}\right)}{w_{0}} \times 100 \\
& \text { Su içeriği }(\%)=\frac{\left(w_{s}-w_{0}\right)}{w_{s}} \times 100
\end{aligned}
$$

Kompozit hidrojel doku iskelelerinin viskoelastik özellikleri, basma modunda vücut sıcaklı̆̆ yürüme ve koșma adım frekans değerlerini de içine alan $0,1 \mathrm{~Hz}$ ile $100 \mathrm{~Hz}$ arasında dinamik frekans tarama modu kullanılarak dinamik mekanik analiz (DMA) cihazı (TA, Q800) ile belirlenmistir. Analiz sonunda örneklerin depolama (E') ile kayıp modülleri (E") ölçülmüș ve sönümleme kapasitesinin bir ölçüsü olan tan $\delta$ (E"/ E') değerleri hesaplanmıştır.

Doku iskelelerinin bası yüklemeleri altındaki mekanik özelliklerinin tayini için basma testi uygulanmıştır. Basma testinde, $10 \mathrm{~mm}$ çapında ve $5 \mathrm{~mm}$ kalınlığındaki silindirik numuneler, $\% 80$ deformasyona kadar $0,5 \mathrm{~mm} / \mathrm{s}$ 'lik sabit bir hız ile sıkıștırılmıștır. Bütün deneyler, oda sıcaklığında üc tekrarlı gerçekleștirilmiștir. Doku iskelelerin basma modülleri gerilimgerinim eğrilerinin başlangıç doğrusal bölgesinin eğimi alınarak hesaplanmıştır.

\subsection{In-vitro hücre kültürü çalışmaları}

Elde edilen doku iskelelerinin hücre kültürü çalışmaları için tavşan mezenkimal kök hücreler (tMKH) kullanılmıştır. tMKH'leri Yeni Zellanda Beyaz tavşanlarının aksiyel iskeletinden elde edilmiștir. İlk olarak, tavşanlar steril koşullarda $5 \mathrm{mg} / \mathrm{kg}$ ksilazin ve $35 \mathrm{mg} / \mathrm{kg}$ ketamin ile anestezi altına alınmıștır. Deri dezenfekte edildikten sonra lumbar bölgesinin arkasından sırasıyla cilt, cilt altı, kemik zarı ve kemiğe girilerek, kemik iliği 1,5 $\mathrm{mm}$ biyopsi iğnesi kullanılarak heparin içeren enjektörlere toplanmıștır. Tavşanlardan elde edilen kemik iliği aspirasyonu tMKH'lerin izolasyonu için hücre kültürü laboratuvarına transfer edilmiștir. Hücre kültürü çalıșmaları Dokuz Eylül Üniversitesi, Biyomekanik Anabilim Dalı'nda bulunan GMP laboratuvarında aseptik koşullara uygun olarak gerçekleştirilmiştir.

\subsection{1. tMKH ların izolasyonu}

Tavşanlardan elde edilen kemik iliği Biocool Seperation kullanılarak densite gradient yöntemi ile tabakalandırılmış ve 3000 rpm'de santrifüj edilerek mononüklear tabaka toplanmıștır. Elde edilen hücreler \%10 FBS (fetal sığır serumu), \%1 penisilin- streptomisin ve 200 $\mathrm{mM}$ L-glutamin ile desteklenmiş DMEM-HG büyüme ortamı ile $37^{\circ} \mathrm{C}$ sicaklıkta $\% 5 \mathrm{CO}_{2}$ ve $\% 95$ nem içeren inkübatörde 14 gün boyunca kültüre edilmiştir. Hücre kültürünün devamlılığının sağlanması amacıyla büyüme ortamı haftada iki kez tazelenmiş ve kültür süresince hücreler inverted mikroskop ile gözlenmiştir.

\subsection{2. tMKH ların akım sitometrik analizi}

tMKH'lerin akım sitometrik analizleri, 3. pasaj sonrasında, FACS ArialII akım sitometri cihazı 
kullanılarak gerçekleștirilmiștir. Hücreler Tripsin/EDTA kullanılarak tripsinizasyon ișlemi ile kaldırılıp, sayım yapılmış ve hücre sayısı

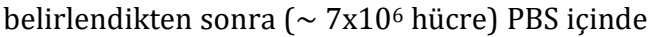
homojenize edilmiștir. Ardından tMKH'ler, CD 73 (APC), CD 90 (FITC), CD 34 (PE), CD 45 (PerCP/Cy5.5) tavşan hücre yüzey belirteçlerine özel monoklonal antikorlar ile işaretlenmiștir. 20 dakika boyunca oda sıcaklığında, karanlıkta inkübe edilen hücreler $1200 \mathrm{rpm}$ 'de 5 dakika santirüj edilerek yıkanmıștır. Hücreler FACS Aria III akım sitometri cihazı ile önce tanımlanmıș ardından hücre ayrımlama işlemi yapılarak ayrılmıștır. Ardından FaxDiva Software programı ile veriler elde edilmiștir.

\subsubsection{Tavşan mezenkimal kök hücrelerin farklılaştırılması}

Farklılaşma kapasitelerinin belirlenmesi için hücreler osteojenik, kondrojenik ve adipojenik olarak farklılaștırılmıștır. Hücreler 3. pasaj sonrasında 6 kuyucuklu kültür kabına 3000 hücre/ml konsantrasyonda ekilmiş, osteojenik, kondrojenik ve adipojenik farklılaşma besi yerleri içerisinde $37^{\circ} \mathrm{C}$ ve $\% 5 \quad \mathrm{CO}_{2}$ içeren inkübatörde kültüre edilmiștir.

tMKH'lerin osteojenik farklılaşması için, hücreler $100 \mathrm{nM}$ dexamethasone, $0.05 \mu \mathrm{M}$ askorbik asit, $10 \mathrm{mM} \quad \beta$-gliserofosfat, \%1 penisilin-streptomisin, $200 \mathrm{mM}$ L-glutamin ve $\% 10$ FBS içeren MEM kültür medyumunda inkübe edilmiştir. Kültürün 4 . haftasında kalsifikasyon bölgelerinin incelenmesi amaciyla hücreler alizarin kırmızısı ile boyanarak osteojenik farklılaşma ışı mikroskobunda gözlenmiștir.

tMKH'lerin kondrojenik farklılaşması için, içerisinde \%10 FBS, \%1 penisilin-streptomisin, $100 \mu \mathrm{M}$ deksamethazon, $10 \mathrm{ng} / \mathrm{ml}$ TGF $\beta, 50$ $\mu \mathrm{g} / \mathrm{ml}$ askorbik asit ve $50 \mathrm{mg} / \mathrm{ml}$ ITS+Premiks bulunan DMEM-HG kıkırdaklașma ortamı kullanılmıștır. Kültürün 4. haftası sonunda, kondrositler tarafindan üretilen proteoglikanların varlığının belirlenmesi için alcian mavisi ile boyanarak ışık mikroskobu kullanılarak incelenmiștir.

tMKH'leri adipojenik farklılaşması için, \%10 FBS $200 \mathrm{mM}$ L-glutamin, $\quad 0.5 \mathrm{mM}$ isobutilmetilksantin, 10M deksametazon, $10 \mu \mathrm{g} / \mathrm{ml} \mathrm{IGF}$, $200 \mu \mathrm{M}$ indometasin ve $\% 1$ penisilinstreptomisin eklenmiş MEM besi ortamı kullanılmıstır. Kültürün 4. haftası sonunda, intrasellüler yağ damlacıklarının varlığının belirlenmesi için adipojenik farklılasmayı gösteren Oil red 0 ile boyanmıştır.

\subsubsection{Doku iskelelerine tMKH'lerin ekimi}

Hücre ekimi öncesinde elde edilen doku iskeleleri etilen oksit ile steril hale getirilmiștir. Hücre ekimi için tMKH'ler yukarıda verilen kondrojenik farklılaşma ortamında çoğaltılmış ve 4. hafta sonunda farklılaşmış kondrosit hücreleri kullanılmıștır. Hazırlanan doku iskeleleri $\left(1 \times 1 \times 0,5 \mathrm{~cm}^{3}\right)$ üzerine, $1 \times 10^{6}$ hücre $/ \mathrm{ml}$ konsantrasyonda kondrosit hücreleri ekilmiștir. Doku iskeleleri kıkırdaklaşma ortamı içerisinde $37^{\circ} \mathrm{C}, \quad \% 5 \quad \mathrm{CO}_{2}$ içeren \%95 nem içeren inkübatörde 14 gün boyunca inkübe edilmiştir.

\subsubsection{In-vitro sitotoksisite analizi}

Doku iskelelerinin hücreler üzerindeki toksik etkisi hücre kültürün 3,7 ve 14 . günlerinde gerçekleștirilmiştir. İlk olarak Laktat dehidrojenaz (LDH) kiti içerisinde bulunan hücre lizis çözeltisi hücre medyumuna eklenmiş ve 45 dakika boyunca $37^{\circ} \mathrm{C}^{\prime}$ de inkübasyona bırakılmıştır. Ardından medyum içeriği 96 kuyucuklu plakalara alınarak içerisine reaksiyon karıșımı eklenmiș ve 30 dakika boyunca inkübe edilmiștir. İnkübasyon sonunda ortama salınan LDH miktarı 490-680 $\mathrm{nm}$ dalga boyunda kolorimetrik olarak spektrofotometre (Sinergy HTX) ile ölçülmüştür.

\subsubsection{In-vitro proliferasyon analizi}

Hidrojel doku iskelelerine ekilen hücrelerin proliferasyonu kültürün 3,7 ve 14 . günlerinde WST-1 kiti kullanılarak araştırılmıştır. Doku iskeleleri üzerine WST-1 boyası eklenerek 4 saat boyunca $37^{\circ} \mathrm{C}, \% 5 \mathrm{CO}_{2}$ içeren $\% 95$ nem içeren inkübatörde inkübe edilmiştir. İnkübasyon sonunda $440 \mathrm{~nm}$ dalga boyunda absorbans ölçümleri yapılarak metabolik aktiviteye bağlı olarak hücrelerin proliferasyon kapasiteleri belirlenmiștir.

\subsubsection{Kollajen analizi}

Doku iskelelerinin üzerine ekilen hücrelerinin ürettiği kollajen miktarı hidroksiprolin miktarına bağlı olarak hücre kültürünün 14 ve 21. günlerinde analiz edilmiştir. İlk olarak hücreler $95^{\circ} \mathrm{C}$ 'de hidroliz edilmiștir. Ardından kit talimatları uygulanarak örnekler hazırlanmış ve $550 \mathrm{~nm}$ dalga boyunda kolorimetrik ölçüm yapılarak total kollajen miktarı belirlenmiştir. 


\subsection{8. İstatistiksel analiz}

In-vitro deneyler 3 tekrarlı olarak gerçekleștirilmiştir. Elde edilen deneysel veriler ortalama \pm standart sapma olarak gösterilmiștir. Gruplar arasındaki farklılıklar Tukey'in çoklu karşılaştırma testi ile tek yönlü varyans analizi (One-way Analysis of Variance (ANOVA) with Tukey's multiple comparison test) ile belirlenmiș ve $\mathrm{p}<0,05$ anlamlılık düzeyi esas alınarak istatistiksel olarak değerlendirilmiștir.

\section{Bulgular}

\subsection{Hidrojel doku iskelelerinin karakterizasyonu}

Doku iskeleleri kitosan-ipek polimerleri kullanılarak hazırlanmış, genipin çapraz bağlayıcısı kullanılarak hidrojel özellik kazandırılmıştır. Çalışmada ilk olarak çapraz bağlanma süresi optimize edilmiștir. Tablo 1'de doku iskelelerinin isimlendirilmeleri ve ilave edilen genipinin konsantrasyonları verilmektedir. Şekil 1A, B ve C'de ilave edilen genipin çözeltisi sonrasındaki kitosan-ipek süngerlerin sırası ile 12, 24 ve 48 saat sonundaki görüntüleri yer almaktadır. 48 saat sonunda tüm süngerlerde renk değişiminin gerçekleşmesiyle, kovalent çapraz bağlanmalar tamamlanmıştır.
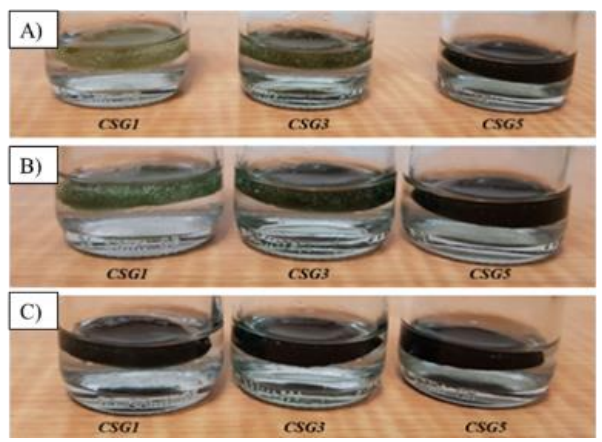

Şekil 1. CS süngerlerin genipin ilavesi sonrası

A) 12 saat, B) 24 saat, C) 48 saat sonraki görüntüleri

\subsubsection{Morfoloji karakterizasyonu}

Çalışmada üretilen hidrojel doku iskelelerinin SEM analizi sonuçları incelendiğinde, bütün doku iskelelerinin açık gözenekli bir yapıya sahip olduğu görülmektedir (Şekil 2). Kontrol grubuna ait SEM görüntülerinde CSG3 doku iskelesinde göreceli olarak daha homojen bir gözenek yapısının elde edildiği görülmektedir. Üretilen kompozit doku iskelelerinde katkı elemanı olarak kullanılan lif kabağının, kitosanipek matrisiyle entegrasyonu sağlamak en önemli unsurdur. Farklı genipin konsantrasyonlarında üretilen doku iskelelelerinin SEM görüntüleri incelendiğinde, lif kabaklarının kitosan-ipek matrisi içerisine entegre olduğu gözlenmiştir.

\subsubsection{Kimyasal yapı karakterizasyonu}

Kitosan-ipek ve lif kabağı katkılı kitosan-ipek hidrojel kompozit doku iskelelerine ait FTIR spektrumları sırası ile Şekil $3 \mathrm{~A}$ ve B'de verilmektedir. $\quad 3400-3000 \mathrm{~cm}^{-1} \quad(\mathrm{O}-\mathrm{H}, \quad \mathrm{N}-\mathrm{H}$ gerilme), $\sim 1640 \mathrm{~cm}^{-1}$ (amid, C=0 gerilme), 1560 $\mathrm{cm}^{-1}$ (N-H gerilme) ve $1100-1000 \mathrm{~cm}-1$ (C-O gerilme) pikleri, kitosanın karakteristik pikleri olup literatürde yer almaktadır [15]. Genipine ait karakteristik pikler ise $\sim 1680 \mathrm{~cm}^{-1}$ (ester, $\mathrm{C}=0$ gerilme), $\sim 1620 \mathrm{~cm}^{-1}$ (C=C gerilme), $1080 \mathrm{~cm}^{-1}$ (C-O gerilme) olarak belirtilmektedir [16]. Ayrıca lif kabağının FTIR absorpsiyon pikleri ise $3400-3200 \mathrm{~cm}^{-1}$ (O-H gerilme), 2928 ve 2845 cm-1 (C-H gerilme), $1737 \mathrm{~cm}^{-1}$ (hemiselülozların ksilan bileşenindeki karbonil ve asetil gruplarının $\mathrm{C}=0$ gerilme titreşimi), $1257 \mathrm{~cm}^{-1}(=$ $\mathrm{C}-\mathrm{O}-\mathrm{C}$ asimetrik gerilmesi) ve $1047 \mathrm{~cm}^{-1}$ (C-O-C piranoz halka iskelet titreșimi) olarak verilmektedir [17]. Üretilen hidrojel doku iskelelerinin FTIR spektrumlarında, çapraz bağlanma reaksiyonu, amid $\left(\sim 1625 \mathrm{~cm}^{-1}\right)$ ve amino $\left(\sim 1557 \mathrm{~cm}^{-1}\right)$ absorpsiyon bantlarının yükseklikleri arasındaki orandaki bir artışla doğrulanabilir ve ayrıca genipin konsantrasyonunun artmasıyla bu oranın arttığ da görülmüştür. Ayrıca genipin konsantrasyonu arttıkça, genipin yapısında bulunan C-O germe bandındaki artıșa bağlı olarak $1060 \mathrm{~cm}^{-1}$ 'deki tepe de genişlemiştir. FTIR analizinde yaklaşık $1625 \mathrm{~cm}^{-1}$ dalga sayısında, ipek ve kitosana ait amid bantları çakışmakta, bu sebeple ipek konformasyonu net olarak gözlenememektedir. Ayrıca, lif kabağındaki hemiselülozun $\mathrm{C}=\mathrm{O}$ gerilme bandı ile ilişsilendirilen $1735 \mathrm{~cm}^{-1}$ 'deki tepe görülmemiştir, bu nedenle lif kabaklarına uygulanan $\mathrm{NaOH}$ ișleminin bașarı ile tamamlandığı sonucu çıkarılmıştır [18]. 
DEÜ FMD 23(69), 937-950, 2021

Tablo 1. Örnek isimlendirmeleri, içerikleri, genipin konsantrasyonları ve su içerikleri

\begin{tabular}{llll}
\hline Örnek & İçerik & $\begin{array}{l}\text { Genipin Konsantrasyonu } \\
\text { (ağırlıkça \% }(\mathbf{w} / \mathbf{v}) \mathbf{c}\end{array}$ & $\begin{array}{l}\text { Su İçeriği } \\
\text { (\%) }\end{array}$ \\
\hline CS & Kitosan-İpek & - & - \\
CSG1 & Kitosan-İpek & 0,1 & $98,0 \pm 0,3$ \\
CSG3 & Kitosan-İpek & 0,3 & $97,0 \pm 0,1$ \\
CSG5 & Kitosan-İpek & 0,5 & $97,8 \pm 0,1$ \\
L-CS & Lif kabağı- Kitosan-İpek & - & - \\
L-CSG1 & Lif kabağı- Kitosan-İpek & 0,1 & $93,4 \pm 0,6$ \\
L-CSG3 & Lif kabağı- Kitosan-İpek & 0,3 & $94,4 \pm 0,2$ \\
L-CSG5 & Lif kabă̆ı- Kitosan-İpek & 0,5 & $93,9 \pm 0,4$ \\
\hline
\end{tabular}
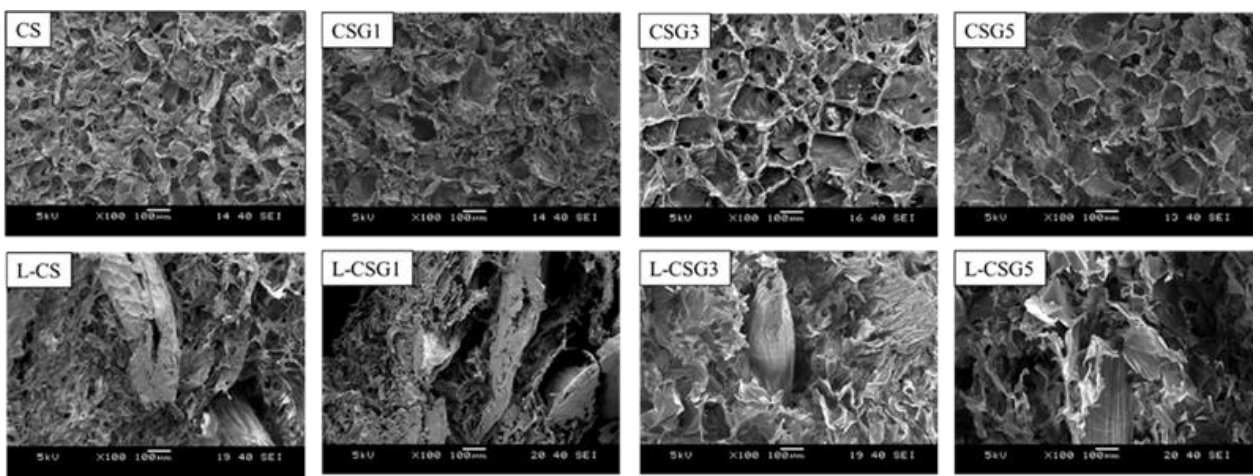

Şekil 2. Kitosan-ipek ve lif kabağı katkılı kitosan-ipek hidrojel kompozit doku iskelelerinin SEM görüntüleri
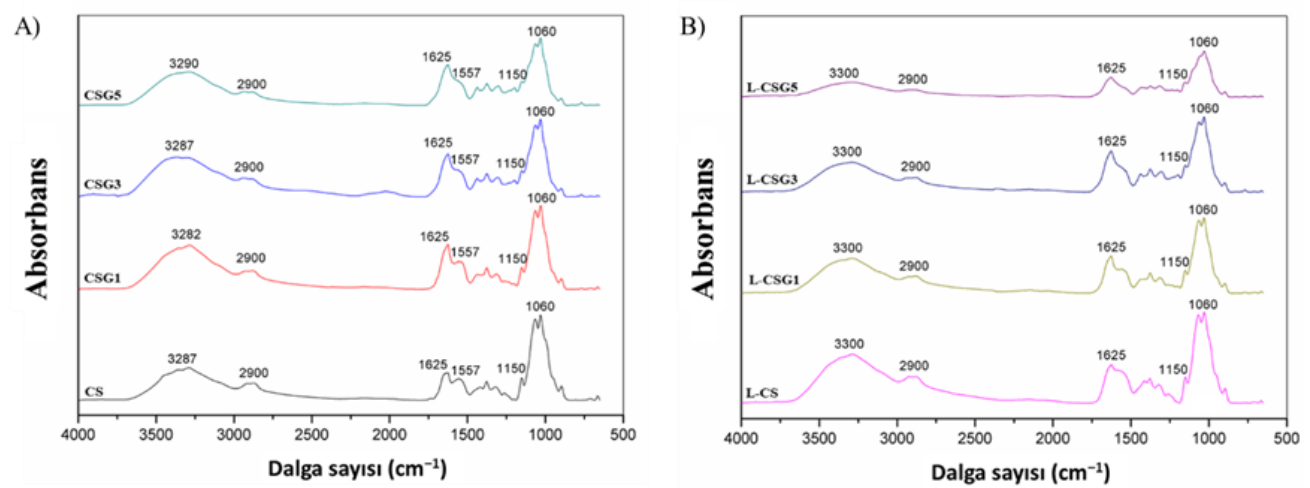

Şekil 3. A) Kitosan-ipek ve B) lif kabağı takviye edilmiş kitosan-ipek doku iskelelerinin FTIR spektrumları 


\subsection{3. Şişme testi}

Tablo 1'den görüldüğü gibi, tüm hidrojel doku iskeleleri \%92 ile 98 su içeriğine sahiplerdir. Hidrojel doku iskelelerinin \% șișme oranlar incelendiğinde (Şekil 4), lif kabağı takviyesi olmayan kitosan-ipek hidrojel doku iskeleleri arasında genipin konsantrasyonun artması ile şişme oranlarında azalma gözlenmiştir. Kompozit hidrojel doku iskelelerinin şișme oranı değerleri arasında anlamlı bir fark gözlenmemiștir. Ancak, lif kabağ takviyesinin kompozit doku iskelelerinin şişme oranı değerlerini kontrol grubuna kıyasla yaklaşık üçte biri oranında düşürdüğü gözlenmiștir.

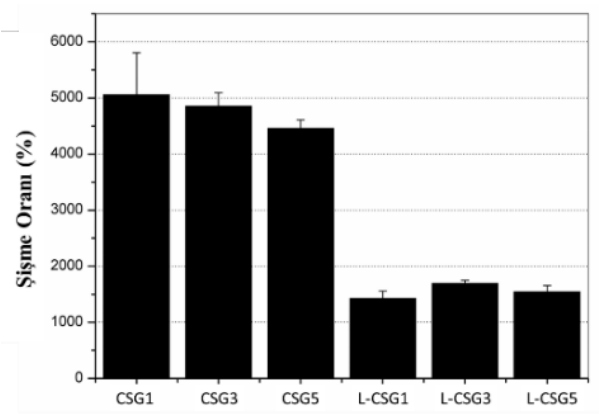

Şekil 4. Hidrojel doku iskelelerinin şişme oranları

\subsubsection{Viskoelastik özellik karakterizasyonu}

Şekil 5A ve B, sırası ile kitosan-ipek ve lif kabağı takviye edilmiș kitosan-ipek hidrojel doku iskelelerinin depolama ve kayıp modülü değerlerini göstermektedir. Analiz sonucunda elde edilen depolama modülü ( $\left.E^{\prime}\right)$, malzemenin elastik tepkisini, enerji depolama kabiliyetini ifade ederken; kayıp modülü (E") malzemenin enerji dağıtma, yayma kabiliyetini ifade eder. Tüm doku iskelelerinin E' değerlerinin kayıp modül değerlerinden büyük olduğu görülmektedir. Lif kabağı takviyesi ile kompozit hidrojel doku iskelelerinin depolama modüllerinde düșüș gözlense dahi, bütün kompozit doku iskelelerinin depolama modül değerleri yükselen frekans ile artıș göstermiștir (Şekil 5B). Bu da kompozit doku iskelelerinin viskoelastik davranış gösterdiğinin kanıtıdır. Viskoelastik bir malzemenin E" ile E' arasındaki oran $\tan \delta$ değeri olarak tanımlanırken ve bu değer malzemenin enerji sönümleme kapasitesi hakkında bilgi verir. Kontrol grubuna ve kompozit doku iskelelerine ait örneklerin $\tan \delta$ logaritma frekans eğrileri Şekil 6A'da verilmektedir. Yetișkin bir insanın yürüme frekansı 0,6 ve $1,1 \mathrm{~Hz}$ değerlerinde iken koșma frekansı 1,5 Hz değerinin üzerine çıkar [19]. LCSG3 doku iskelesi bu frekanslarda daha yüksek tan delta değerine sahiptir.

\subsubsection{Mekanik test}

Basma deneyleri sonucunda elde edilen gerilimgerinim eğrilerinden her numune için $\% 7$ ve \%15 birim şekil değiștirme aralığındaki lineer bölge kullanılarak basma modülleri hesaplanmıștır (Şekil 6B). Lif kabağı takviyesiz kontrol grubu numunelerinde genipin oranı değișimi ile basma modülünde anlamlı bir değişim gözlenmezken, lif kabağı takviyeli kompozit doku iskelelerinde genipin oranındaki artış ile basma modül değerleri artmaktadır. Kontrol grubu numunelerinin ortalama basma modül değerleri yaklaşılk 1-2 MPa iken, lif kabaklı kompozit doku iskelelerinde ise yaklaşık 5-9 MPa değerlerindedir.

\subsection{In-vitro biyouyumluluk çalışmaları}

Gözenekli yapısı, yeterli su içeriği, viskoelastik özelliği, yüksek tan $\delta$ değeri ve yeterli basma modülü dolayısı ile L-CSG3 doku iskelesi optimum olarak seçilmiş ve in-vitro biyouyumluluk çalışmaları bu doku iskelesi ile gerçekleştirilmiştir. In-vitro analiz sonuçları kitosan (CG3), lif kabağı takviyeli kitosan (LCG3), ve kitosan-ipek (CSG3) doku iskeleleri ile karşılaştırılmıştır.

\subsection{1. tMKH ların akım sitometrik analizleri}

Tavşan kemik iliğinden izole edilen tMKH'lerin 2. (Şekil 7a) ve 3. pasaj sonrasında (Şekil 7A, b) iğsi şeklinde ve fibroblast benzeri morfolojiye sahip olduğu gözlenmiștir. 3. Pasaj sonrasında $\sim 7 \times 10^{6}$ hücre elde edildiği hücre sayımı ile belirlenmiş ve hücrelerin tanımlanması için akım sitometrik analizler gerçekleștirilmiștir. Analiz sonuçlarında belirtilen P1 bölgesi analiz edilen tüm hücreleri, $\mathrm{P} 2$, $\mathrm{P} 3, \mathrm{P} 4$ ve $\mathrm{P} 5$ ise sirasiyla CD45, CD90, CD34 ve CD73 yüzey belirteçleri ile analiz edilen hücreleri göstermektedir (Şekil 7B). Akım sitometrik analiz sonuçlarında, hücrelerin CD45 ve CD34 belirteçlerine göre negatif ve CD90 ve CD73 belirteçlerine pozitif ekspresyon gösterdiği saptanmıştır. Elde edilen verilere göre izole edilen hücrelerin \%74,7'sinin pozitif tMKH belirteçlerini eksprese ettiği ve \%2,8'inin negatif tMKH belirteçlerini eksprese ettiği belirlenmiș ve pozitif olan hücrelerin ayrımlama işlemi ile hücre kültürüne devam edilmiștir. 
DEÜ FMD 23(69), 937-950, 2021
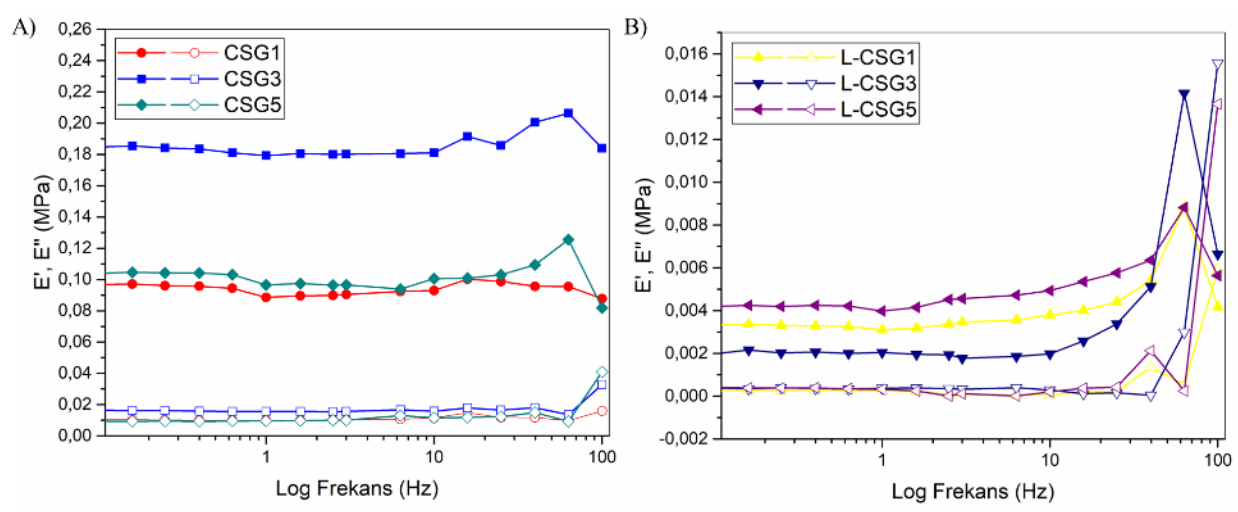

Şekil 5. A) Kitosan-ipek ve B) Lif kabağı takviyeli kitosan-ipek hidrojel doku iskelelerinin depolama (E', içi dolu sembol) ve kayıp modülleri (E', içi boş sembol)
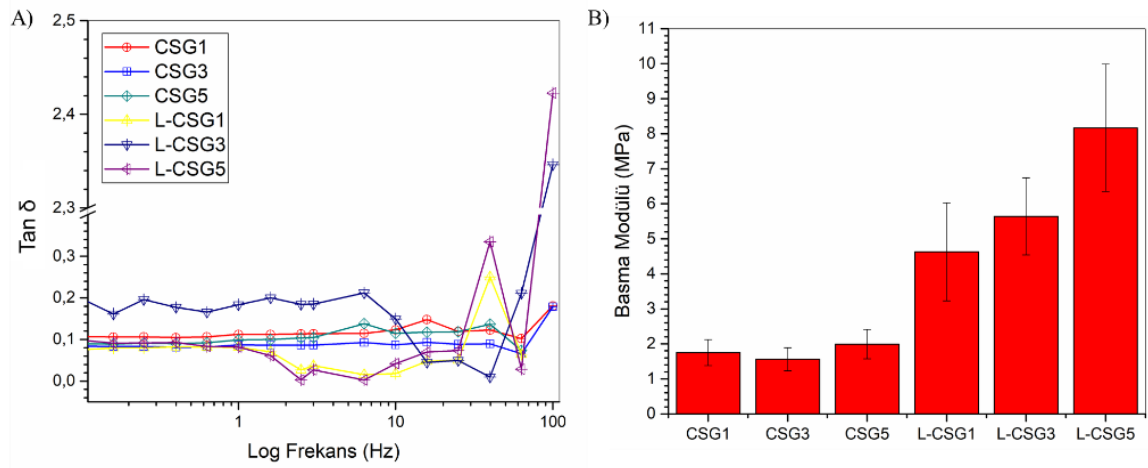

Şekil 6. Hidrojel doku iskelelerinin A) tan delta ve B) basma modülü değerleri

\subsection{2. tMKH'lerin Farklılaşma Kapasiteleri}

Osteoblast, kondrosit ve adiposit farklılaşma için tMKH'leri 4 hafta boyunca sirasiyla osteojenik, kondrojenik ve adipojenik besiyerleri ile kültüre edilmiştir. Osteojenik farklılaşmayı belirlemek amacıyla Alizarin kırmızısı ile boyanan oval şekilli hücrelerin mineralizasyon birikimleri kırmızı renkte gözlenmiş ve osteoblast benzeri hücrelere farklılaştıkları belirlenmiştir (Şekil 7d). Kondrojenik farklılaşmayı incelemek için hücreler Alcian mavisi ile boyanmıştır ve kondrojenik farlılaşmayı işaret eden, kondrositler tarafından üretilen proteoglikanlar mavi renkte gözlenmiştir (Şekil 7e). Adipojenik farklılaşmada ise Oil red 0 boyaması sonrasında hücrelerde oluşan yağ damlacıkları hücre sitoplazmasında parlak kırmızı renkte gözlemlenmiș ve adiposit benzeri hücrelere farklılaştıkları belirlenmiştir (Şekil 7f). Farklılaşma kapasiteleri belirlenen tMKH'ler, doku iskelelerine ekilmek üzere kondrojenik farklılaştırılmış hücreler kullanılarak hücre kültürüne devam edilmiștir. 


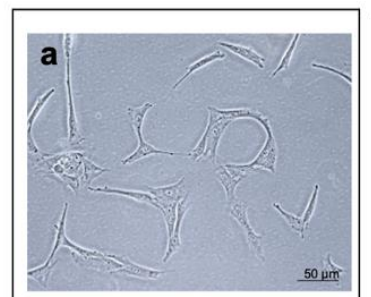

C
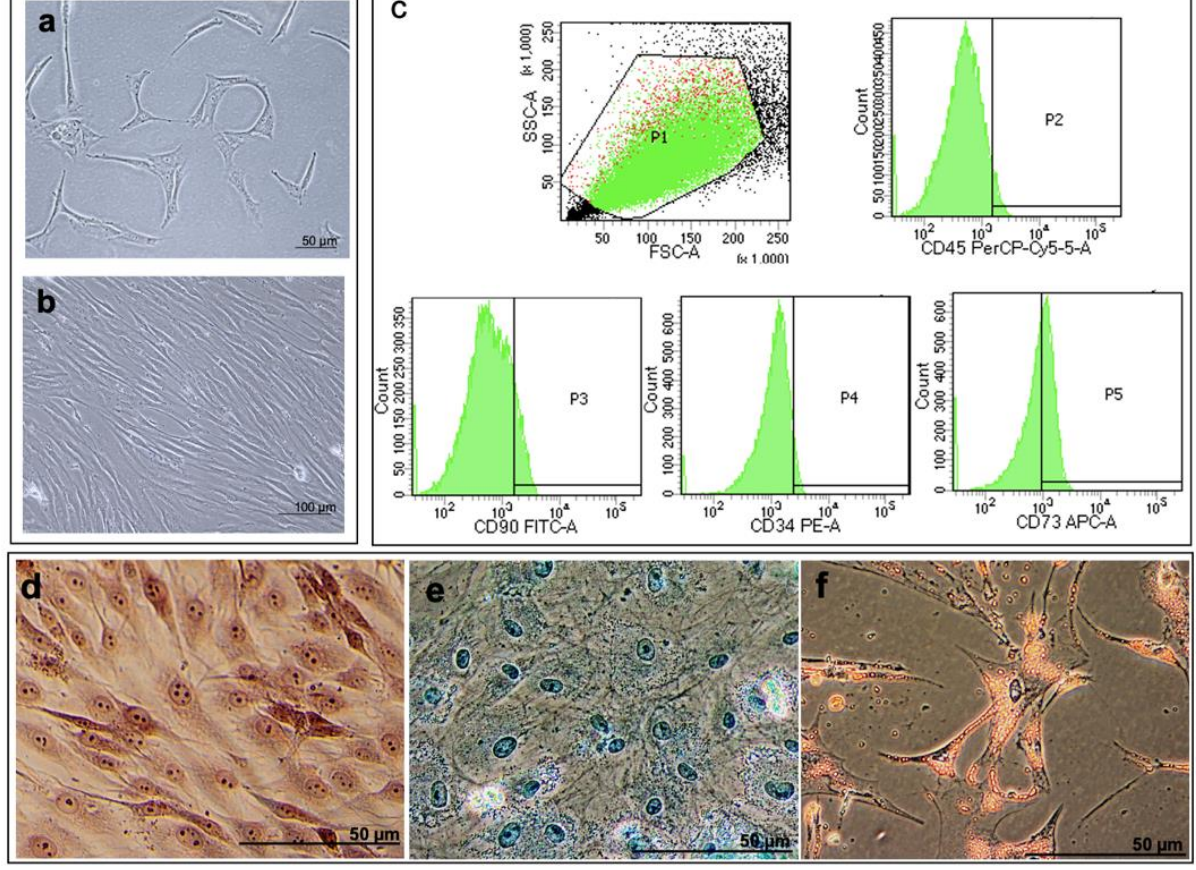

Şekil 7. Tavşan kemik iliklerinden izole edilen tMKH'lerin (a) 2. ve (b) 3. pasaj sonrasındaki görünümleri, c) akım sitometrik analiz sonuçları, d) osteojenik, e) kondrojenik ve f) adipojenik farklılaştırılmış hücrelerin görüntüleri
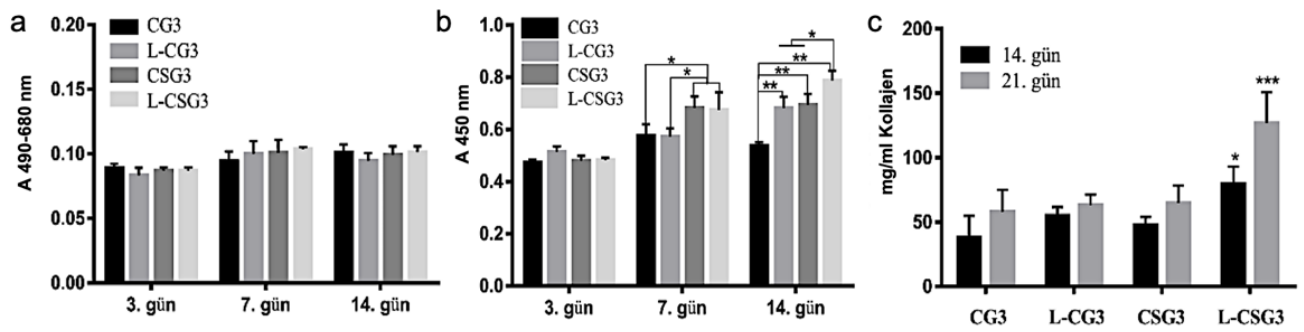

Şekil 8. Doku iskelelerine ekilmiş hücrelerin LDH sitotoksisite, WST-1 proliferasyon ve kollajen analiz sonuçları

\subsubsection{Sitotoksite analizi}

Doku iskelelerinin sitotoksik etkisi hücre kültürünün 3,7 ve 14 . günlerinde gerçekleştirilmiştir. LDH analizi sonuçlarına göre, tüm doku iskelesi gruplarında LDH seviyeleri oldukça düşük ve benzer oranda görülmektedir (Şekil 8a). Tüm gruplardaki LDH seviyeleri 7. ve 14. günlerde 3. güne göre nispeten yüksek görülse de istatistiksel olarak anlamlı bir fark saptanmamıştır.

\subsubsection{Proliferasyon analizi}

Doku iskeleleri üzerine ekilen hücrelerin proliferasyonu 3,7 ve 14 . günlerde WST-1 analizi ile incelenmiştir (Şekil 8b). 3. günde tüm doku iskelesi gruplarında hücre benzer oranda çoğaldığı belirlenmiş ve istatistiksel olarak anlamlı bir fark bulunmamıștır. Kültürün 7. ve 14. günlerinde gruplar arasında farklılıklar gözlenmiştir. 7. günde tüm gruplarda artış gözlenmiş olup CSG3 ve L-CSG3 doku iskelelerinde diğer gruplara göre istatistiksel olarak anlamlı artış saptanmıştır. Kültürün 14. 


\section{DEÜ FMD 23(69), 937-950, 2021}

gününde CG3 doku iskelesi üzerindeki hücrelerin diğer gruplara göre daha az çoğaldığ görülmektedir. L-CSG3 doku iskelesine bakıldığında ise diğer gruplardan daha yüksek oranda çoğalma kapasitene sahip olduğu ve diğer gruplar ile karşılaştırıldığında istatistiksel olarak anlamlı fark olduğu görülmektedir. Aynı zamanda CSG3 ve L-CG3 doku iskeleleri arasında anlamlı bir fark saptanmamış fakat her iki doku iskelesinin L-CSG3 ile arasında istatistiksel olarak anlamlı fark olduğu bulunmuștur. L-CSG3 hidrojel kompozit doku iskelesi içeriğindeki ipeğin hücrelerin çoğalmasında etkili olduğu görülmektedir. 14 günlük kültür sürecinde LCSG3 doku iskelesindeki kondrojenik hücrelerin düzenli artan bir trende sahip olduğu ve diğer gruplar ile karşılaştırıldığında hücrelerin proliferasyonunu arttırdığı gösterilmiștir.

\subsubsection{Kollajen analizi}

Doku iskelelerine ekilen kondrojenik hücreler tarafından üretilen kollajen miktarları hücre kültürünün 14. ve 21. günlerinde ölçülmüştür (Şekil 8c). Kollajen miktarlarının tüm doku iskelesi gruplarında 21. günde arttığ görülmektedir. L-CSG3 doku iskelesindeki kondrojenik hücrelerin ürettiği kollajen miktarı diğer gruplar ile karşılaştırıldığında hem 14. günde hem de 21. günde istatistiksel olarak anlamlı farklılık olduğu saptanmıştır.

\section{Tartışma ve Sonuç}

Hidrojel olușumu, zincirler arasında ikincil kimyasal etkileșimler ya da iyonik etkileşimler ile gerçekleșen fiziksel çapraz bağlanma veya kovalent bağların oluştuğu kimyasal çapraz bağlanma ile gerçekleşmektedir. Çalışmada, kitosanın ve ipeğin amino grupları ile genipin arasında gerçekleşen kovalent çapraz bağlanma reaksiyonu sonucunda doku iskeleleri koyu mavi bir renk almaktadır. FTIR analizi ile de gerçekleşen bu reaksiyon kanıtlanmıştır. Ayrıca, çapraz bağlayıcı konsantrasyonun artması ile çapraz bağlanma süresi azalmaktadır.

Biyomedikal alanında kullanılacak polimerik malzemeler için yüzey özellikleri büyük önem taşır. Hücre tutunması ve büyümesi açısından üretilmiş olan gözenekli doku iskelelerinde gözenek boyutu ve yapısı önem taşımaktadır.

Uygulama alanı ve hedef hücre tipine göre istenilen gözenek boyutu büyüklüğü değişkenlik gösterebilirken, gözenek yapısının açık gözenekli olması gerekmektedir. Çalışmada üretilen kompozit doku iskeleleri ve kontrol grubunun SEM analizi sonuçları incelendiğinde, bütün doku iskelelerinin açlk gözenekli bir yapıya sahip olduğu görülmektedir. Ayrıca SEM görüntüleri, Image J program kullanılarak incelenmiş ve gözenek boyutunun 150-200 $\mu \mathrm{m}$ aralığında değiștiği belirlenmiştir. Yan ve arkadaşlarının 2010 yılında yaptıkları çalışmada, eklem kıkırdağı hasarını gidermek için geliştirdikleri kitosan-kolajen doku iskelelerinin gözenek boyutlarının 100-200 $\mu \mathrm{m}$ aralığında olduğu belirtilmiștir [20].

Kıkırdak ekstrasellüler matrisi hidrofilik bir ortam olduğu için doku iskelesinin şişme davranışı değerlendirilmesi gereken önemli bir husustur. Literatürde kıkırdağın ıslak ağırlığının yaklașık \%80'ine kadar su içerdiği belirtilmiștir [21]. Üretilen hidrojel kompozit doku iskeleleri \% 92-94 su içerikleri ile, besin maddelerine karşı iyi geçirgenlik, hücrelerin kolay büyümesi, uygun şişme kinetiği ve doğal ekstrasellüler matrise benzer hidratlı bir ortam sağlarlar $[22,23]$.

Eklem kıkırdağı, kıkırdağa sürekli karmaşık mekanik yüklemeye dayanma yeteneği kazandıran viskoelastisiteye sahip yük taşıyıcı bir dokudur. $\mathrm{Bu}$ nedenle, kıkırdak rejenerasyonunda kullanılacak doku iskelelerinin viskoelastik özellikte olması önem arz etmektedir [24]. Bütün kompozit doku iskelelerinin E' değerleri yükselen frekans ile artış göstermiştir. $\mathrm{Bu}$ da kompozit doku iskelelerinin viskoelastik davranış gösterdiğinin bir kanıtıdır. Literatürde insan eklem kıkırdağının $1 \mathrm{~Hz}$ frekanstaki tan $\delta$ değeri 0,266 olarak belirtilmiştir. Kontrol grubuna ait $\tan \delta$ değerleri bu değerin altında kalmaktadır. Lif kabağı takviyeli kompozit doku iskelelerinde bu değere en çok yaklaşan örnek L-CSG3 olmuştur [25].

Kompozit doku iskelelerinin basma modül değerlerinde diğer doku iskelesine göre artıș gözlenmiştir. $\mathrm{Bu}$ da lif kabağının doku iskelesinde takviye malzemesi olarak görev aldığının bir kanıtıdır. Ayrıca, üretilen doku iskelelerinin basma modül değerleri, literatürde belirtilen insan eklem kıkırdağının basma modül değeri ile $(\sim 1,75 \mathrm{MPa})$ uyumludur [26].

LDH, pek çok hücre tipinde bulunan sitoplazmik bir enzimdir. Hücrelerin plazma zarında oluşturulan hasar ile LDH enzimi hücre kültürü ortamına salınır. Böylece ortamdaki LDH, 


\section{DEÜ FMD 23(69), 937-950, 2021}

laktatın pirüvata dönüșümünü kataliz eden enzimatik reaksiyon sonucunda ölçülebilmektedir. Ölçülen seviye, sitotoksisitenin göstergesi olan ortama salınan LDH miktarı ile doğru orantılıdır $[27,28]$. LDH analizi sonuçlarına göre, tüm doku iskelesi gruplarında LDH seviyelerinin oldukça düşük seviyelerde görülmektedir. Hücre kültürü süresünce LDH seviyesinin düşük seviyelerde seyretmesi ve artış göstermemesi, doku iskelelerinin herhangi bir toksik etki göstermediğini belirtmektedir.

Hücrelerin üç boyutlu yapılar üzerinde canlılığını devam ettirmesi, çoğalması ve uygun biyokimyasal ortam olușturması doku yenilenmesi ve hazırlanan malzemenin doku tamirindeki ișlevselliğini arttırmaktadır [29]. Doku iskelelerine ekilen kondrojenik hücrelerin proliferasyon analiz sonuçlarına göre en yüksek L-CSG3 doku iskelesi üzerinde hücrelerin çoğaldığı ve kültür günlerine göre artan bir proliferasyon kapasitesi gösterdiği saptanmıştır. Doku iskelesinde bulunan hem kitosan, hem de ipek bileşiminin yanı sıra lif kabağı takviyesinin hücre proliferasyon kapasitesini arttırdığı düșünülmektedir. Daha önceden rapor edilen çalışmalara göre lif kabağının kıkırdak hücreleri için uygun bir üç boyutlu yapı sağladığı ve hücre çoğalmasını tetiklediği gösterilmiştir [12]. Çalıșmamızda elde edilen sonuçlarda, literatür ile uyumlu olarak, L-CSG3 doku iskelesindeki lif kabağı katkısının kondrojenik hücrelerin çoğalması için uygun bir ortam sağladığı görülmektedir.

Kıkırdak dokunun en önemli ve en yoğun bulunan matriks proteini kollajendir ve doku yenilenmesinde önemli bir role sahiptir [30]. Kıkırdak doku yenilenmesi için tasarlanan doku iskelesinin kıkırdak dokuyu taklit edebilmesi ve hem fizyolojik hem de biyokimyasal olarak kıkırdak doku özelliklerini göstermesi gerekir [31]. Doku iskeleleri üzerindeki hücrelerin kollajen üretimi dokuyu taklit etmesi açısından önemli bir faktördür [32]. Doku iskelelerine ekilen kondrojenik hücreler tarafından üretilen kollajen miktarları tüm doku iskelesi gruplarında 21. günde arttığı görülmektedir. LCSG3 doku iskelesindeki kondrojenik hücrelerin ürettiği kollajen miktarı diğer gruplar ile karşılaştırıldığında daha fazla olduğu görülmüştür. L-CSG3 hidrojel doku iskelesinin, proliferasyon sonuçlarına benzer olarak, kondrojenik hücreler için daha uygun bir ortam sağladığını, L-CSG3 doku iskelesinde hücrelerin daha fazla çoğaldığı ve daha fazla miktarda kollajen ürettiği belirlenmiştir. Böylelikle, kompozit LCS-G3 hidrojel doku iskelesine ekilen kondrojenik hücrelerin proliferasyon sonuçlarına benzer şekilde, kondrojenik hücrelerin daha fazla çoğaldığı ve daha fazla miktarda kollajen ürettiği belirlenmiştir.

Sonuç olarak, tüm bu bulgular doğrultusunda LCSG3 hidrojel kompozit doku iskelesinin kıkırdak doku hasarında kullanılabilme potansiyeli olduğu söylenebilir.

\section{Teşekkür}

Bu çalıșma Dokuz Eylül Üniversitesi Bilimsel Araștırma Projeleri tarafından, 2016.KB.MLT.002 proje numarası ile desteklenmiștir. Yazarlar akım sitometrik analizler için İzmir Biyotıp ve Genom Merkezi'ne, dinamik mekanik analiz için Prof. Dr. Metin TANOĞLU ve Mehmet Deniz GÜNEȘ'e teșekkür etmektedirler.

\section{Kaynakça}

[1] Ahmadi, F., Giti, R., Mohammadi-Samani, S., Mohammadi, F. 2017. Biodegradable Scaffolds for Cartilage Tissue Engineering. Galen Medical Journal, Cilt. 6 (2), s. 70-80. DOI: 10.22086/GMJ.V6I2.696

[2] Armiento, A., Stoddart, M., Alini, M., Eglin, D. 2017. Biomaterials for articular cartilage tissue engineering: Learning from biology. Acta Biomaterialia, Cilt. 65, s. 1-20. DOI: $10.1016 /$ j.actbio.2017.11.021

[3] Seol, Y.J., Park, J.Y., Jeong, W., Kim, T.H., Kim, S.Y., Cho, D.W. 2015. Development of Hybrid Scaffolds Using Ceramic and Hydrogel for Articular Cartilage Tissue Regeneration. Journal of Biomedical Materials Research Part A, Cilt. 103 (4), s. 1404-1413. DOI: 10.1002/jbm.a.35276

[4] Saladino, S., Di Leonardo, E., Salamone, M., Mercuri, D., Segatti, F., Ghersi, G. 2014. Formulation of Different Chitosan Hydrogels for Cartilage Tissue Repair. Chemical Engineering Transactions, Cilt. 38, s. 505510. DOI: $10.3303 /$ CET 1438085

[5] O'brien, F.J. 2011. Biomaterials \& Scaffolds for Tissue Engineering. Materials Today, Cilt. 14 (3) s. 88-95. DOI: 10.1016/S1369-7021(11)70058-X

[6] Puppi, D., Chiellini, F., Piras, A., Chiellini, E. 2010. Polymeric Materials for Bone and Cartilage Repair. Progress in Polymer Science, Cilt. 35 (4), s. 403-440. DOI: $10.1016 /$ j.progpolymsci.2010.01.006

[7] Yang, J., Zhang, Y.S., Yue, K., Khademhosseini, A. 2017. Cell-Laden Hydrogels for Osteochondral and Cartilage Tissue Engineering. Acta Biomaterialia, Cilt. 57, s. 125. DOI: $10.1016 /$ j.actbio.2017.01.036

[8] Vepari, C., Kaplan, D.L. 2007. Silk as a Biomaterial. Progress in Polymer Science, Cilt. 32 (8), s. 991-1007. DOI: $10.1016 /$ j.progpolymsci.2007.05.013 


\section{DEÜ FMD 23(69), 937-950, 2021}

[9] Mirahmadi, F., Tafazzoli-Shadpour, M., Shokrgozar, M.A., Bonakdar, S. 2013. Enhanced Mechanical Properties of Thermosensitive Chitosan Hydrogel by Silk Fibers for Cartilage Tissue Engineering. Materials Science and Engineering: C, Cilt. 33 (8), s. 4786-4794. DOI: 10.1016/j.msec.2013.07.043

[10]Bas, O., De-Juan-Pardo, E.M., Meinert, C., D’Angella, D., Baldwin, J.G., Bray, L.J., Wellard, R.M., Kollmannsberger, S., Rank, E., Werner, C. 2017. Biofabricated Soft Network Composites for Cartilage Tissue Engineering. Biofabrication, Cilt. 9 (2), s. 025014. DOI: 1088/1758-5090/aa6b15

[11]11. Butcher, A.L., Offeddu, G.S., Oyen, M.L. 2014 Nanofibrous Hydrogel Composites as Mechanically Robust Tissue Engineering Scaffolds. Trends in Biotechnology, Cilt. 32 (11), s. 564-570. DOI: 10.1016/j.tibtech.2014.09.001

[12] Cecen, B., Kozaci, L.D., Yuksel, M., Ustun, O., Ergur, B.U., Havitcioglu, H. 2016. Biocompatibility and Biomechanical Characteristics of Loofah Based Scaffolds Combined with Hydroxyapatite, Cellulose, Poly-l-lactic acid with Chondrocyte-like Cells. Materials Science and Engineering: C, Cilt. 69, s. $437-$ 446. DOI: $10.1016 /$ j.msec.2016.07.007

[13]Varaprasad, K., Raghavendra, G.M., Jayaramudu, T., Yallapu, M.M., Sadiku, R. 2017. A Mini Review on Hydrogels Classification and Recent Developments in Miscellaneous Applications. Materials Science and Engineering: C, Cilt. 79, s. 958-971. DOI: 10.1016/j.msec.2017.05.096

[14] Dimida, S., Barca, A., Cancelli, N., De Benedictis, V., Raucci, M.G., Demitri, C. 2017. Effects of Genipin Concentration on Cross-Linked Chitosan Scaffolds for Bone Tissue Engineering: Structural Characterization and Evidence of Biocompatibility Features. International Journal of Polymer Science, Cilt. 2017, s. 1-8. DOI: /10.1155/2017/8410750

[15] Li, Q., Wang, X., Lou, X., Yuan, H., Tu, H., Li, B., Zhang, Y. 2015. Genipin-crosslinked Electrospun Chitosan Nanofibers: Determination of Crosslinking Conditions and Evaluation of Cytocompatibility. Carbohydrate Polymers, Cilt. 130 , s. 166-174. DOI 10.1016/j.carbpol.2015.05.039

[16] Delgadillo-Armendariz, N.L., Rangel-Vazquez, N.A Marquez-Brazon, E.A., Gascue, R-D. 2014. Interactions of Chitosan/Genipin Hydrogels During Drug Delivery: A QSPR Approach. Química Nova, Cilt. 37 (9), s. 15031509. DOI: 10.5935/0100-4042.20140243

[17] Abdelwahab, 0. 2014. Assessment of Raw Luffa as a Natural Hollow Oleophilic Fibrous Sorbent for Oil Spill Cleanup. Alexandria Engineering Journal, Cilt. 53 (1), s. 213-218. DOI: 10.1016/j.aej.2013.11.001

[18] Botaro, V.R., Novack, K.M., Siqueira, E.J. 2012. Dynamic Mechanical Behavior of Vinylester Matrix Composites Reinforced by Luffa Cylindrica Modified Fibers. Journal of Applied Polymer Science, Cilt. 124 (3), s.1967-1975. DOI: 10.1002/app.35019
[19]Vacanti, C. 2008. Musculoskeletal Tissue Regeneration: Biological Materials and Methods. Humana Press, 670s.

[20]Yan, L.P., Wang, Y.J., Ren, L., Wu, G., Caridade, S.G., Fan, J.B., Wang, L.Y., Ji, P.H., Oliveira, J.M., Oliveira, J.T. 2010. Genipin-cross-linked Collagen/Chitosan Biomimetic Scaffolds for Articular Cartilage Tissue Engineering Applications. Journal of Biomedical Materials Research Part A, Cilt. 95 (2), s. 465-475. DOI: 10.1002/jbm.a.32869

[21]Sophia Fox, A.J., Bedi, A., Rodeo, S.A. 2009. The Basic Science of Articular Cartilage: Structure, Composition, and Function. Sports Health, Cilt. 1 (6), s. 461-468. DOI: $10.1177 / 1941738109350438$

[22]Yodmuang, S., McNamara, S.L., Nover, A.B., Mandal, B.B., Agarwal, M., Kelly, T-AN., Chao, P-hG., Hung, C., Kaplan, D.L., Vunjak-Novakovic, G. 2015. Silk Microfiber-reinforced Silk Hydrogel Composites for Functional Cartilage Tissue Repair. Acta Biomaterialia, Cilt. 11, s. 27-36. DOI: 10.1016/j.actbio.2014.09.032

[23]Lee, C-T., Kung, P-H., Lee, Y-D. 2005. Preparation of Poly (vinyl alcohol)-chondroitin Sulfate Hydrogel as Matrices in Tissue Engineering. Carbohydrate

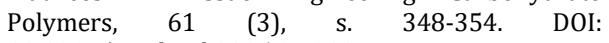
10.1016/j.carbpol.2005.06.018

[24]Chen, K., Zhang, D., Yang, X., Zhang, X., Wang, Q. 2016. Research on Viscoelastic Behavior and Mechanism of Hydrogel Grafted with UHMWPE. Soft Materials, 14 (4), s. 244-252. DOI: 10.1080/1539445X.2016.1195408

[25]Temple, D.K., Cederlund, A.A., Lawless, B.M., Aspden, R.M., Espino, D.M. 2016. Viscoelastic Properties of Human and Bovine Articular Cartilage: A Comparison of Frequency-Dependent Trends. BMC Musculoskeletal Disorders, Cilt. 17 (1), s. 419. DOI: 10.1186/s12891-016-1279-1

[26]Bartnikowski, M., Wellard, R., Woodruff, M., Klein, T. 2015. Tailoring Hydrogel Viscoelasticity with Physical and Chemical Crosslinking. Polymers, Cilt. 7 (12), s. 2650-2669. DOI: 10.3390/polym7121539

[27]Dinescu, S., Gălăţeanu, B., Albu, M., Lungu, A., Radu, E., Hermenean, A., Costache, M. 2013. Biocompatibility Assessment of Novel Collagen-Sericin Scaffolds Improved with Hyaluronic Acid and Chondroitin Sulfate for Cartilage Regeneration. BioMed Research International 2013. DOI: 10.1155/2013/598056

[28]Kumar, P., Nagarajan, A., Uchil, P.D. 2018. Analysis of Cell Viability by the Lactate Dehydrogenase Assay. Cold Spring Harbor Protocols, Cilt. 2018 (6), s. prot095497. DOI:10.1101/pdb.prot095497

[29]Mabrouk, M., Beherei, H.H., Das, D.B. 2020. Recent Progress in the Fabrication Techniques of 3D Scaffolds for Tissue Engineering. Materials Science and Engineering: C, Cilt. 110, s. 110716. DOI: 10.1016/j.msec.2020.110716

[30]Chen, J-L., Duan, L., Zhu, W., Xiong, J., Wang, D. 2014. Extracellular Matrix Production In Vitro in Cartilage 
DEÜ FMD 23(69), 937-950, 2021

Tissue Engineering. Journal of Translational Medicine, Cilt. 12 (1), s. 88. DOI:10.1186/1479-5876-12-88

[31]Francis, S.L., Di Bella, C., Wallace, G.G., Choong, P.F. 2018. Cartilage Tissue Engineering Using Stem Cells and Bioprinting Technology-Barriers to Clinical Translation. Frontiers in Surgery, Cilt. 5, s. 70. DOI: 10.3389/fsurg.2018.00070

[32] 32. Irawan, V., Sung, T-C., Higuchi, A., Ikoma, T. 2018 Collagen Scaffolds in Cartilage Tissue Engineering and Relevant Approaches for Future Development. Tissue Engineering and Regenerative Medicine, Cilt. 15 (6), s. 673-697. DOI: 10.1007/s13770-018-0135-9 